\title{
The Relationship Between Duration of Hemodialysis, Helicobacter pylori and CagA Seropositivity in Patients with Chronic Kidney Disease
}

\section{Kronik Böbrek Hastalarında Hemodiyaliz Süresi, Helicobacter pylori ve CagA Seropozitiflig̃i Arasındaki îlișki}

Og̃uzhan ÖZCAN'(IDD), Hüseyin ERDAL 2,3(IID), Burçin ÖZER (IID), Filiz KAÇMAZ²(IID), Faruk TURGUT5(IID)

\footnotetext{
${ }^{1}$ Department of Medical Biochemistry, Faculty of Medicine, Hatay Mustafa Kemal University, Hatay, Turkey

${ }^{2}$ Department of Molecular Biochemistry and Genetics, Institute of Health Sciences, Hatay Mustafa Kemal University, Hatay, Turkey

${ }^{3}$ Department of Medical Genetics, Faculty of Medicine, Aksaray University, Aksaray, Turkey

${ }^{4}$ Department of Medical Microbiology, Faculty of Medicine, Hatay Mustafa Kemal University, Hatay, Turkey

${ }^{5}$ Department of Nephrology, Faculty of Medicine, Hatay Mustafa Kemal University, Hatay, Turkey
}

Cite this article as: Özcan O, Erdal H, Özer B, Kaçmaz F, Turgut F. Kronik böbrek hastalarında hemodiyaliz süresi, Helicobacter pylori ve CagA seropozitifliği arasındaki ilişki. FLORA 2020;25(3):383-90.

\begin{abstract}
Introduction: The aim of this study was to investigate the relationship between Helicobacter pylori occurrence and, Cytotoxinassociated gene A (CagA) seropositivity with hemodialysis (HD) duration, Serum C-reactive protein (CRP) and hemogram parameters in hemodialysis patients.

Materials and Methods: This study included 165 prevalent HD patients. Blood samples were collected before dialysis treatment of the patients. The samples were then centrifuged at $1500 \times \mathrm{g}$ for $10 \mathrm{~min}$. immediately after collection. The presence of serum IgG antibody for $\mathrm{H}$. pylori was determined using commercial ELISA kits. Serum anti-CagA IgC antibody of H. pylori positive patients was determined by ELISA method using commercial ELISA kits. CRP levels were measured by nephelometric method, and hemogram parameters were analyzed using fully automated hematology analyzer.

Results: We found that the CRP levels of the patients having H. pylori were significantly high. However, there was no significant difference between CRP levels of long-term hemodialysis (LTHD) and short-term hemodialysis (STHD) patients. The possibility of being seropositive of CagA for STHD patients having H. pylori was found to be 2.3 times higher than that of LTHD patients. In addition to that, the periodicity of gastrointestinal (GI) bleeding was significantly high in STHD patients.

Conclusion: In conclusion, we found no relationship between dialysis duration and H. pylori prevalence. However, we observed significantly higher odds ratio for CagA seropositivity in patients receiving STHD. These findings suggest that longer dialysis treatment can cause improving effects on $\mathrm{H}$. pylori virulence. Further studies are needed to verify these findings.
\end{abstract}

Key Words: H. pylori; Hemodialysis; CagA 


\title{
Kronik Böbrek Hastalarında Hemodiyaliz Süresi, Helicobacter pylori ve CagA Seropozitifliği Arasındaki İlișki
}

\author{
Og̃uzhan ÖZCAN', Hüseyin ERDAL ${ }^{2,3}$, Burçin ÖZER ${ }^{4}$, Filiz KAÇMAZ², Faruk TURGUT ${ }^{5}$
}

\footnotetext{
${ }^{1}$ Hatay Mustafa Kemal Üniversitesi Tıp Fakültesi, Tıbbi Biyokimya Anabilim Dalı, Hatay, Türkiye

${ }^{2}$ Hatay Mustafa Kemal Üniversitesi, Sag̃ılı Bilimleri Enstitüsü, Moleküler Biyokimya ve Genetik Anabilim Dalı, Hatay, Türkiye

${ }^{3}$ Aksaray Üniversitesi Tıp Fakültesi, Tıbbi Genetik Anabilim Dalı, Aksaray, Türkiye

${ }^{4}$ Hatay Mustafa Kemal Üniversitesi Tıp Fakültesi, Tıbbi Mikrobiyoloji Anabilim Dalı, Hatay, Türkiye

${ }^{5}$ Hatay Mustafa Kemal Üniversitesi Tıp Fakültesi, Nefroloji Anabilim Dalı, Hatay, Türkiye
}

Giriş: Bu çalışmanın amacı, hemodiyaliz hastalarında Helicobacter pylori oluşumu ve CagA seropozitifliğinin hemodiyaliz (HD) süresi, Serum C-reaktif protein (CRP) ve hemogram parametreleri arasındaki ilişkiyi araştırmaktır.

Materyal ve Metod: Bu çalışmaya 165 yaygın HD hastası dahil edildi. Hastaların diyaliz tedavisinden önce kan örnekleri alındı. Numuneler daha sonra vakit kaybetmeden 10 dakika 1500 x g'de santrifüjlendi. H. pylori için serum IgG antikorunun varlığı ticari ELISA kitleri kullanılarak belirlenmiştir. H. pylori pozitif hastaların serum anti-CagA IgG antikoru, ticari ELISA kitleri kullanılarak ELISA yöntemi ile belirlenmiştir. CRP düzeyleri nefelometrik yöntemle ve hemogram parametreleri ise tam otomatik hematoloji analizörü kullanılarak analiz edildi.

Bulgular: H. pylori pozitif hastaların CRP düzeylerinin anlamlı derecede yüksek olduğunu bulduk. Bununla birlikte uzun dönem hemodiyaliz (UDHD) ve kısa dönem hemodiyaliz (KDHD) hastalarının CRP düzeyleri arasında anlamlı bir fark yoktu. H. pylori pozitif olan KDHD hastalarında CagA'nın seropozitif olma olasılığı, UDHD hastalarından 2.3 kat daha fazla bulunmuştur. Buna ek olarak gastrointestinal kanamasının periyodikliği KDHD hastalarında anlamlı derecede yüksekti.

Sonuç: Sonuç olarak diyaliz süresi ile H. pylori prevalansı arasında bir ilişki bulamadık. Bununla birlikte, KDHD alan hastalarda CagA seropozitifliği için anlamlı olarak daha yüksek olasılık oranı gözlemledik. Bu bulgular, daha uzun diyaliz tedavisinin $\mathrm{H}$. pylori virülansı üzerinde iyileştirici etkilere neden olabileceğini düşündürmektedir. Bu bulguları doğrulamak için daha fazla çalışmaya ihtiyaç vardır.

Anahtar Kelimeler: Helicobacter pylori; Hemodiyaliz; CagA

\section{INTRODUCTION}

The incidence of chronic kidney disease (CKD) is a widespread and significant health problem that has increased rapidly and caused the death of more than one million people worldwide $e^{[1]}$. CKD is caused by chronic diseases such as diabetes, hypertension and renal parenchymal disease ${ }^{[2,3]}$ and characterized as the fluid-solute imbalance due to a decrease in glomerular filtration rate (GFR). Another important clinical manifestation is increased gastrointestinal lesions including peptic ulcus, gastritis, gastric adenoma and perforation caused by Helicobacter pylori infection ${ }^{[4,5]}$. It has been reported that the prevalence of $H$. pylori is increased in uremic patients compared to the healthy population ${ }^{[6]}$. The increase in uremic toxins and oxidative stress due to the decrease in GFR is known to pave the way for the formation of chronic inflammation and immunodeficiency, whi- ch causes inclination to $H$. pylori infection ${ }^{[7]}$. Increased ammonia in these patients facilitates the survival of $H$. pylori ${ }^{[8]}$. However, the underlying mechanism is still unclear ${ }^{[9]}$.

$H$. pylori virulence is gaining importance as another contributing factor for gastric lesions in these patients ${ }^{[5]}$. H. pylori produces many virulence factors; "cytotoxin-associated gene A (cagA)" is one of them. This gene encodes a 121-145 $\mathrm{kDa}$ immuno-dominant protein (CagA) that, when injected into the gastric epithelial cell cytoplasm, interacts with host cell proteins, inducing cell morphological changes and pro-inflammatory and mitogenic responses ${ }^{[10]}$. The presence of the CagA gene is an important marker for most virulent strains associated with peptic ulcer, atrophic gastritis and adenocarcinoma. The CagA gene is associated with more serious clinical consequences of the cag pathogenicity island and 
other genes on the island. These factors are also used as epidemiological markers. CagA plays a role in determining the clinical outcome of infections ${ }^{[10]}$. However, it has been reported that patients colonized by CagA-containing strains have more severe gastric inflammation ${ }^{[6]}$. On the other hand, these genes encode for CagA proteins, which stimulate anti-body formation in infected patients ${ }^{[11]}$. Serologic testing for these antibodies has been found to be a sensitive method for detecting infection with cagA-positive strains ${ }^{[12]}$. In a study, the sensitivity of $\operatorname{IgG}$ anti-CagA antibody in identifying patients with cagA-positive strains has been found as $97.67 \%[13]$. In another study, cagA IgG antibodies titer has been found to be associated with persistence of $H$. pylori infection ${ }^{[14]}$. In the literature, there are studies showing the prevalence of $H$. pylori in CKD patients, but conflicting results are reported. Some results have shown that the occurrence of $H$. pylori is increased in some studies ${ }^{[15,16]}$; however, some other reports show a decrease in the occurrence of $H$. pylori ${ }^{[17,18]}$. There are many studies investigating the relationship between $H$. pylori positivity and duration of dialysis, but there is no study between CagA seropositivity and dialysis duration.

In this study, we aimed to investigate the relationship between $H$. pylori occurrence and CagA seropositivity with hemodialysis (HD) duration and laboratory parameters in hemodialysis patients.

\section{MATERIALS and METHODS}

The study included 165 HD patients. Patients were arbitrarily divided into two groups depending on the duration of $\mathrm{HD}$ treatment: group 1 is composed of short-term HD (STHD), receiving less or equal of 36 months of treatment; group 2 is constituted of long-term HD (LTHD), receiving more than 36 months of treatment. Demographic and clinical data including frequency of gastrointestinal bleeding of the patients obtained from the patient files and laboratory information system and the duration of dialysis were recorded. Fasting venous blood samples were collected into $8.5 \mathrm{~mL}$ BD Vacutainer SST II Advance tubes (Becton, Dickinson \& Co, Franklin Lakes, NJ) from all patients and centrifuged at $1500 \times \mathrm{g}$ for $10 \mathrm{~min}$. immediately after collection. Patient sera were stored in the freezer at $-80^{\circ} \mathrm{C}$. The presence of serum IgG and anti-CagA IgG antibody for $H$. pylori was determined using commercial ELISA kits (DIA.PRO, Italy and NovaTec, Helg 0220, Gemany, respectively). Diagnostic performance of $H$. pylori kits; sensitivity and specifity are $98.1 \%$ and $93.0 \%$, respectively. Intra-assay $\mathrm{CV}$ is $<7.2$ and inter-assay $\mathrm{CV}$ is $<$ 6.5\%. For CagA; Sensitivity and spasticity are > $98 \%$ and reproducibility is ranging $4-20 \%$. Serum total protein, albumin, blood urea nitrogen (BUN), creatinine and phosphorus levels were measured by spectrophotometric method and sodium and potassium levels by ISE method in the routine auto analyzer (Siemens Advia, USA). Serum $\mathrm{C}$-reactive protein (CRP) levels were assayed by nephelometric method (Siemens BN II, Germany). Whole blood samples were collected by EDTA containing tubes and were measured by complete blood count analyzer (Mindray BC-6800, China). Medical consent was obtained from the patients included into the study in accordance with the Helsinki Ethical Issues Declaration.

The institutional Ethics Committee of Hatay Mustafa Kemal University approved the study (protocol number: 1003201605).

\section{Statistics}

Analysis of the study data was carried out using SPSS (IBM, USA) for Windows, version 21. Data normality was examined with the Kolmogorov-Smirnov test. Qualitative data were evaluated using the Chi-square test and quantitative data were tested utilizing the Kruskal-Wallis and Mann-Whitney $U$ test. Values of $p<0.05$ were regarded as statistically significant.

\section{RESULTS}

A total of 165 adult patients, including 93 (56\%) males and 72 (44\%) females with a mean age of $60.7 \pm 12.2$ years were included in the study. Average duration of HD treatments for patients with both STHD and LTHD were calculated to be respectively $18.6 \pm 10.4$ months and $91.6 \pm 41.1$ months. Clinical and demographic characteristics of patients having both STHD and LTHD treatments groups were shown in Table 1. The most frequent underlying disease was diabetes mellitus (Table 1). We found that the total number of patients with $H$. pylori was 
Table 1. Demographic and clinical characteristics of the patients based on duration on hemodialysis

\begin{tabular}{lccc} 
& $\begin{array}{c}\text { Short term Hemodialysis } \\
(\mathbf{n}=53)\end{array}$ & $\begin{array}{c}\text { Long term Hemodialysis } \\
(\mathbf{n}=112)\end{array}$ & $\mathbf{p}$ \\
\hline Female/male & $28 / 25$ & $43 / 69$ & 0.080 \\
Age (years) (mean $\pm \mathrm{sd})$ & $61.30 \pm 13.95$ & $60.44 \pm 11.28$ & 0.673 \\
Dyspepsia (n, \%) & $8(15 \%)$ & $28(25 \%)$ & 0.1503 \\
Gastrointestinal bleeding (n, \%) & $15(28 \%)$ & $14(13 \%)$ & 0.0128 \\
Diabetes mellitus (n, \%) & $31(58.5 \%)$ & $47(41.9 \%)$ & 0.0295 \\
Hypertension (n, \%) & $10(18.8 \%)$ & $23(20.5 \%)$ & 0.2042 \\
Polycystic kidney (n, \%) & $3(5.7 \%)$ & $3(2.7 \%)$ & 0.3394 \\
Other (n, \%) & $9(16.9 \%)$ & $39(34.8 \%)$ & 0.1508 \\
\hline
\end{tabular}

STHD $\leq 36$ months; LTHD $>36$ months $P<0.05$ is significant.

Table 2. The effect of hemodialysis duration on prevalence of $H$. pylori infection

\begin{tabular}{|c|c|c|c|c|c|}
\hline & $\begin{array}{l}\text { Short-term Hemodialysis } \\
\qquad(n=53)\end{array}$ & $\begin{array}{l}\text { Long term Hemodialysis } \\
\qquad(n=112)\end{array}$ & OR & $\mathrm{Cl}(95 \%)$ & $\mathbf{p}$ \\
\hline H. pylori (+) & $31(\% 58)$ & $70(\% 63)$ & 1.16 & $0.6-2.24$ & 0.654 \\
\hline H. pylori (-) & $22(\% 42)$ & $42(\% 38)$ & & & \\
\hline H. pylori (+)- CagA(+) ${ }^{1}$ & $14 / 31(\% 45)$ & $21 / 70(\% 30)$ & 2.28 & $1.02-5.11$ & 0.043 \\
\hline H. pylori (+)- CagA(-) & $17 / 31(\% 55)$ & $50 / 70(\% 71)$ & & & \\
\hline
\end{tabular}

101 (61\%). In addition, CagA seropositivity was found in 35 (34.7\%) of the 101 patients with H. pylori. The possibility of CagA seropositivity for STHD patients was found to be 2.3 times higher than that of LTHD patients $(p=0.043$, Table 2). In this study, we also found that the CRP levels of the patients with $H$. pylori were higher than those of the patients without $H$. pylori ( $p=0.004$, Table 4). However, there was no significant difference between CRP levels of LTHD and STHD patients ( $p=0.901$, Table 3). In addition to that, the periodicity of GIS bleeding was significantly high in the STHD patients $(p=0.013$, Table 4).

\section{DISCUSSION}

There are no other reports in the literature investigating the relationship between incidence of $H$. pylori and CagA seropositivity with dialysis duration and inflammation parameters for chronic kidney disease (CKD) patients receiving hemodialysis treatment. In this study, we found that the patients with $H$. pylori have significantly higher serum CRP levels than the patients without $H$. pylori. However, dialysis duration had no effect on CRP levels. The possibility of CagA seropositivity for STHD patients was found to be 2.28 times higher than that of LTHD patients. In addition to that, the periodicity of GIS bleeding was significantly high in the STHD patients.

In the literature, there are conflicting results in terms of $H$. pylori prevalence in HD patients. Some studies have reported high incidence of $H$. pylori in HD patients $(n=151,64.9 \%)^{[16]}$. They suggested that this high level could be caused by the demographic and clinical characteristic differences of the patients. In other studies, the incidence of $H$. pylori has been reported to be low ( $\mathrm{n}=51,27.5 \%)$ or steady $(\mathrm{n}=127,60 \%)$ in HD patients ${ }^{[17-19]}$. They suggested that urea and nitrogen levels in gastric secretions of dialysis patients were higher than normal patients and this high level could inhibit the increase of $H$. pylori in the stomach ${ }^{[20]}$. Some others speculated that $H$. pylori could be abolished by using antibiotic therapy in the first stage of treatment ${ }^{[21]}$. 
Table 3. Laboratory parameters of the patients based on hemodialysis duration

\begin{tabular}{|c|c|c|c|}
\hline Laboratory tests* & $\begin{array}{l}\text { Short term Hemodialysis } \\
\qquad(n=53)\end{array}$ & $\begin{array}{l}\text { Long term Hemodialysis } \\
\qquad(n=112)\end{array}$ & $\mathbf{p}$ \\
\hline BUN (mg/dL) & $65.8 \pm 15.9$ & $70.10 \pm 16.03$ & 0.121 \\
\hline Creatinine (mg/dL) & $8.5 \pm 2.5$ & $9.17 \pm 2.50$ & 0.137 \\
\hline $\mathrm{HgB}(\mathrm{g} / \mathrm{dL})$ & $10.7 \pm 1.8$ & $11.5 \pm 1.3$ & 0.012 \\
\hline Total protein (g/dL) & $6.9 \pm 0.6$ & $6.78 \pm 0.46$ & 0.206 \\
\hline Albumin (g/dL) & $3.9 \pm 0.4$ & $3.89 \pm 0.36$ & 0.315 \\
\hline Sodium (mmol/L) & $139.3 \pm 2.7$ & $138.20 \pm 3.62$ & 0.037 \\
\hline Potassium (mmol/L) & $5.6 \pm 0.9$ & $5.82 \pm 0.91$ & 0.324 \\
\hline Calcium (mg/dL) & $8.6 \pm 0.8$ & $8.55 \pm 0.67$ & 0.933 \\
\hline Phosphorus (mg/dL) & $5.2 \pm 1.4$ & $5.42 \pm 1.32$ & 0.280 \\
\hline CRP (mg/L) median (min;max) & $10.3(0.6 ; 29.4)$ & $7.0(0.4 ; 45.3)$ & 0.901 \\
\hline $\mathrm{WBC}\left(10^{3} / \mu \mathrm{L}\right)$ & $7.69 \pm 2.03$ & $7.49 \pm 2.44$ & 0.596 \\
\hline $\mathrm{RBC}\left(10^{6} / \mu \mathrm{L}\right)$ & $3.97 \pm 0.72$ & $3.86 \pm 0.64$ & 0.342 \\
\hline $\mathrm{MCV}(\mathrm{fL})$ & $90.58 \pm 7.97$ & $90.59 \pm 8.72$ & 0.995 \\
\hline $\mathrm{RDW}+\mathrm{CV}$ & $15.44 \pm 1.52$ & $17.02 \pm 16.04$ & 0.333 \\
\hline Gran (\%) & $62.76 \pm 10.16$ & $66.18 \pm 47.87$ & 0.495 \\
\hline Lym (\%) & $23.47 \pm 7.35$ & $24.78 \pm 7.13$ & 0.293 \\
\hline Mono (\%) & $8.54 \pm 2.93$ & $9.10 \pm 3.19$ & 0.281 \\
\hline Eos (\%) & $4.95 \pm 4.10$ & $4.50 \pm 3.22$ & 0.494 \\
\hline Baso (\%) & $0.20 \pm 0.15$ & $0.21 \pm 0.17$ & 0.516 \\
\hline Gran/lym & $3.06 \pm 1.36$ & $2.84 \pm 1.51$ & 0.372 \\
\hline
\end{tabular}

In the present study, the incidence of $H$. pylori for the patients receiving HD treatment was found to be 61 percent and this result is consistent with the previously reported results from this region by Nagiyev et al. ${ }^{[19]}$. We also found higher CRP levels in patients with $H$. pylori infection [10.3 $(0.6 ; 29.4)]$ but no significant difference between CRP levels of LTHD and STHD patients $(p=0.901)$. CRP is a well-known inflammatory cytokine and expected to be increased in patients with $\mathrm{CKD}$. The relationship between $H$. pylori and HD duration was also evaluated in the literature. Nakajima et al. have reported that the incidence of $H$. pylori after receiving two years or more HD treatment is shown to have significantly decreased ${ }^{[22]}$. However, a limited number of studies have shown that the incidence of $H$. pylori significantly increases with the duration of HD treatment ${ }^{[6,16]}$. Rasmi et al. have shown that the incidence of $H$. pylori in patients $(\mathrm{n}=151)$ receiving long-term hemodialysis treatment (LTHD) is significantly high compared to patients receiving short-term hemodialysis treatment $(\mathrm{STHD})^{[6]}$. $\mathrm{Li}$ and Chen, in their meta-analysis study, have reviewed fourteen studies involving 2087 dialysis patients, 815 of them were $H$. pylori positive, 1272 of them were $H$. pylori negative. They analyzed quantitative and qualitative data and they found that $H$. pylori infection rate was negatively correlated with accumulative dialysis time, and methods of $H$. pylori detection did not influence the association between $H$. pylori infection and accumulative dialysis time ${ }^{[23]}$. In another meta-analysis study, $\mathrm{Gu}$ et al. have determined that those who underwent dialysis longer than four years indeed showed a significantly lower rate of H. pylori infection $(p<0.00001)$ than those with normal renal function, while it is another story when it comes to those who endured dialysis duration shorter than four years $(p=0.27)$ with 
Table 4. Laboratory parameters of the patients based on $H$. pylori infection

\begin{tabular}{lccc} 
& H. pylori $(+)(\mathrm{n}=101)$ & H. pylori $(-)(\mathbf{n}=64)$ & p \\
\hline Laboratory parameters & Mean \pm SD & Mean \pm SD & 0.055 \\
\hline BUN (mg/dL) & $66.69 \pm 16.26$ & $71.77 \pm 15.4$ & 0.182 \\
Creatinine (mg/dL) & $8.73 \pm 2.45$ & $9.30 \pm 2.62$ & 0.318 \\
Total protein (g/dL) & $6.85 \pm 0.52$ & $6.77 \pm 0.46$ & 0.585 \\
Albumin (g/dL) & $3.92 \pm 0.36$ & $3.88 \pm 0.41$ & 0.777 \\
Sodium (mmol/L) & $138.51 \pm 3.31$ & $138.67 \pm 3.50$ & 0.687 \\
Potassium(mmol/L) & $5.73 \pm 0.89$ & $5.80 \pm 1.01$ & 0.723 \\
Calcium (mg/dL) & $8.58 \pm 0.71$ & $8.53 \pm 0.72$ & 0.233 \\
Phosphorus (mg/dL) & $5.21 \pm 1.25$ & $5.50 \pm 1.52$ & 0.004 \\
CRP (mg/L)* median (min;max) & $10.3(0.46 ; 45.34)$ & 0.223 \\
WBC (cellsx109/L) & $7.75 \pm 2.49$ & $7.28 \pm 1.97$ & 0.932 \\
RBC & $3.90 \pm 0.70$ & $3.89 \pm 0.62$ & 0.475 \\
MCV & $90.22 \pm 9.19$ & $91.18 \pm 7.15$ & 0.206 \\
Rdw (\%CV) & $17.33 \pm 16.61$ & $15.13 \pm 1.25$ & 0.324 \\
Gran\# & $4.81 \pm 1.82$ & $4.53 \pm 1.60$ & 0.308 \\
lym\# & $1.83 \pm 0.75$ & $1.73 \pm 0.52$ & 0.070 \\
mono\# & $0.69 \pm 0.34$ & $0.61 \pm 0.17$ & 0.410 \\
eos\# & $0.34 \pm 0.30$ & $0.38 \pm 0.29$ & 0.006 \\
baso\# & $0.013 \pm 0.010$ & $0.019 \pm 0.013$ & 0.415 \\
Gran/lym & $2.99 \pm 1.59$ & $2.80 \pm 1.22$ & \\
\hline P<0.05 is significant. & & \\
\end{tabular}

no difference in $H$. pylori infection rate between the two groups ${ }^{[24]}$. They found that a few studies have shown that $H$. pylori positive patients required a significantly shorter course of dialysis than uninfected patients. Among the included studies, some studies evaluated the relationship between $H$. pylori status and duration of dialysis. However, no statistical significance was observed between $H$. pylori negative and $H$. pylori positive patients. The weighted mean difference between these studies was 4.56 (95\% CI: $-1.55-10.67, p=0.14)$. According to subgroup analysis, dialysis treatments for more than 4 year appear to have a protective effect against $H$. pylori infection. In our study, there was no significant difference detected for the incidence of $H$. pylori between the patients receiving LTHD and STHD. However, the incidence of CagA seropositivity in patients with $H$. pylori infection was found to be 2.3 times higher for the STHD group compared to LTHD $(p=0.043)$. It is well known that the presence of the CagA gene has been associated with the high-level inflammation causing the development of severe gastrointestinal diseases such as peptic ulcer disease and gastric cancer ${ }^{[25]}$. Our results suggested that long term dialysis treatment decreased effect on CagA seropositivity and caused improving effect on $H$. pylori virulence in patients with CKD. We also found that patients receiving STHD were significantly high GI bleeding incidence compared to patients receiving LTHD $(p=0.013)$. This result was also consisted with the higher incidence of CagA seropositivity in STHD group. Since GI bleeding is more common in patients with CKD and multiple factors may be effective in the formation of this situation such as uremic medium, simultaneous drug use, ulcers and using heparin for anticoagulation during dialysis session ${ }^{[26]}$. The role of CagA seropositivity for patients with CKD in GI bleeding is not fully understood up to now. Stack et al. have reported that CagA seropositivity patients with $H$. 
pylori have a higher risk of GI bleeding ${ }^{[27]}$. On the other hand, other researchers have reported that they did not see any significant difference in terms of GI bleeding in CagA seropositivity patients with $H$. pylori. These differences may due to selection criteria and the small sample size of the patients ${ }^{[28,29]}$.

\section{CONCLUSION}

In conclusion, we found no relationship between dialysis duration and $H$. pylori prevalence. However, we observed significantly higher odds ratio for CagA seropositivity in patients receiving STHD. These findings suggest that longer dialysis treatment can cause improving effects on $H$. pylori virulence. Further studies are needed to verify these findings.

\section{ETHICS COMMITTEE APPROVAL}

Approval for the study was obtained from MKU Tayfur Ata Sökmen Medicine Faculty Clinical Research Ethical Committee. (Decision no: 2016/65, Date: 01/03/2016).

\section{CONFLICT of INTEREST}

The authors declare that they have no conflict of interest.

\section{AUTHORSHIP CONTRIBUTIONS}

Concept/Design: OÖ, HE, FK, FT

Analysis/Interpretation: OÖ, HE, BÖ, FK

Data Acquisition: BÖ, FK

Writting: OÖ, HE, BÖ, FT

Final Approval: OÖ, BÖ, FT, HE

\section{REFERENCES}

1. Rafieian-Kopaei M, Beigrezaei S, Nasri H, Kafeshani M. Soy Protein and Chronic Kidney Disease: An Updated Review. Int J Prevent Med 2017;8:105.

2. Geraci G, Mulè G, Mogavero M, Geraci C, Nardi E, Cottone S. Association between uric acid and renal hemodynamics: pathophysiological implications for renal damage in hypertensive patients. J Clin Hypertens 2016;18:1007-14.

3. Mathew AV, Okada S, Sharma K. Obesity related kidney disease. Curr Diabetes Rev 2011;7:41-9.

4. Sezer S, Ibiş A, Özdemir BH, Özdemir FN, Külah E, Boyacı̆̆Iu $S$, et al. Association of Helicobacter pylori infection with nutritional status in hemodialysis patients. Transplant Proc 2004;36:47-9.
5. Sugimoto M, Yamaoka Y. Review of Helicobacter pylori infection and chronic renal failure. Ther Apher Dial 2011;15:1 9.

6. Rasmi Y, Farshid S, Makhdomi K. Effect of duration on hemodialysis on prevalence of Helicobacter pylori infection. Saudi J Kidney Dis Transpl 2012;23:489.

7. Yakoob J, Abbas Z, Khan R, Tariq K, Awan S, Beg MA. Association of Helicobacter pylori and protozoal parasites in patients with chronic diarrhoea. Br J Biomed Sci 2018;75:1059.

8. Vaziri ND, Khazaeli $M$, Nunes $A C$, Harley $K T$, Said $H$, Alipour $\mathrm{O}$, et al. Effects of end-stage renal disease and dialysis modalities on blood ammonia level. Hemodial Int 2017;21:343-7.

9. Chang S-S, Hu H-Y. Lower Helicobacter pylori infection rate in chronic kidney disease and end-stage renal disease patients with peptic ulcer disease. I Chin Med Assoc 2014;77:354-9.

10. da Costa DM, dos Santos Pereira E, Rabenhorst SHB. What exists beyond cagA and vacA? Helicobacter pylori genes in gastric diseases. World J Gastroenterol 2015;21:10563.

11. Abasiyanik MF, Sander E, Salih BA. Helicobacter pylori anti-CagA antibodies: prevalence in symptomatic and asymptomatic subjects in Turkey. Can / Gastroenterol Hepatol 2002; 16:527-32.

12. Cover $T L$, Glupczynski $Y$, Lage AP, Buretta A, Tummuru $M K$, Perez-Perez Gl, et al. Serologic detection of infection with cagA+ Helicobacter pylori strains. I Clin Microbiol 1995;33:1496-500

13. Fakhre-Yaseri $H$, Baradaran-Moghaddam A, Shekaraby $M$, Baradaran HR, Soltani-Arabshahi SK. Evaluating the relationship between serum immunoglobulin $G(\lg G)$ and $A(\lg A)$ anti-CagA antibody and the cagA gene in patients with dyspepsia. Iran J Microbiol 2017;9:97.

14. Ilie M, Dascălu L, Chifiriuc C, Popa M, Constantinescu G, Tanasescu $C$, et al. Correlation of anti-Helicobacter pylori cagA IgG antibodies with resistance to first line treatment, bleeding gastroduodenal ulcers and gastric cancer. Roum Arch Microbiol Immunol 2011;70:101-4.

15. Rasmi Y, Makhdoomi K, Farshid S, Kheradmand F. Seroprevalence of anti-Helicobacter pylori and anticytotoxin-associated gene $A$ antigen antibodies according to $A B O$ blood groups and rhesus status among hemodialysis patients. Iran J Kidney Dis 2011;5:110-3.

16. Khedmat $H$, Ahmadzad-Asl M, Amini M, Lessan-Pezeshki $M$, Einollahi B, Pourfarziani $V$, et al. Gastro-duodenal lesions and Helicobacter pylori infection in uremic patients and renal transplant recipients. Transplant Pro 2007;39:1003-7.

17. Sugimoto M, Sakai K, Kita M, Imanishi J, Yamaoka Y. Prevalence of Helicobacter pylori infection in long-term hemodialysis patients. Kidney Int 2009;75:96-103.

18. Nakajima F, Sakaguchi $M$, Amemoto K, Oka H, Kubo M, Shibahara $N$, et al. Helicobacter pylori in patients receiving long-term dialysis. Am J Nephrol 2002;22:468-72. 
19. Fabrizi F, Martin P, Dixit V, Quan S, Brezina M, Abbey H, et al. Epidemiology of Helicobacter pylori in chronic haemodialysis patients using the new RIBA H. pylori SIA. Nephrol Dial Transplant 1999;14:1929-33.

20. Sugimoto M, Sakai K, Kita M, Imanishi J, Yamaoka Y. Prevalence of Helicobacter pylori infection in long-term hemodialysis patients. Kidney Int 2009;75:96-103.

21. Jalalzadeh $M$, Mirzamohamadi F, Zargham P. Prevalence of Helicobacter pylori in long-term dialysis patients. Nephrourol Mon 2011;3:8-14.

22. Nakajima F, Sakaguchi $M, O k a H$, Kawase $Y$, Shibahara $N$, Inoue $T$, et al. Prevalence of Helicobacter pylori antibodies in long-term dialysis patients. Nephrology 2004;9:73-6.

23. Li K-J, Chen L. Association between duration of dialysis and Helicobacter pylori infection in dialysis patients: a meta-analysis. Int Urol Nephrol 2019;51:1361-70

24. Gu M, Xiao S, Pan X, Zhang G. Helicobacter pylori infection in dialysis patients: a meta-analysis. Gastroenterol Res Pract 2013;2013:785892.

25. Roesler BM, Rabelo-Gonçalves EM, Zeitune JM. Virulence factors of Helicobacter pylori: a review. Clinical Med Insights Gastroentol 2014;7:9-17.

26. Chalasani N, Cotsonis G, Wilcox CM. Upper gastrointestinal bleeding in patients with chronic renal failure: role of vascular ectasia. Am J Gastroenterol 1996;91:2329-32.
27. Stack W, Atherton J, Hawkey G, Logan R, Hawkey C. Interactions between Helicobacter pylori and other risk factors for peptic ulcer bleeding. Aliment Pharmacol Ther 2002; 16:497-506.

28. Santolaria S, Lanas A, Benito R, Perez-Aisa MA, Montoro M, Sainz R. Helicobacter pylori infection is a protective factor for bleeding gastric ulcers but not for bleeding duodenal ulcers in NSAID users. Aliment Pharmacol Ther 1999;13:1511-8.

29. Lanas A, Fuentes J, Benito R, Serrano P, Bajador E, Sainz R. Helicobacter pylori increases the risk of upper gastrointestinal bleeding in patients taking low-dose aspirin. Aliment Pharmacol Ther 2002;16:779-86.

\section{Address for Correspondence/Yazıșma Adresi}

Doç. Dr. Oğuzhan ÖZCAN

Hatay Mustafa Kemal Üniversitesi Tip Fakültesi, Tibbi Biyokimya Anabilim Dal,, Hatay-Türkiye

E-posta: drozan29@hotmail.com 